\title{
Ongoing outbreak of aseptic meningitis in south-eastern Latvia, June - August 2010
}

J Perevoscikovs (jurijs.perevoscikovs@lic.gov.lv) ${ }^{1}$, A Brila $^{1}$, L Firstova ${ }^{1}$, T Komarova $^{1}$, I Lucenko ${ }^{1}$, J Osmjana ${ }^{1}$, L Savrasova ${ }^{1}$, I

Singarjova ${ }^{1}$, J Storozenko ${ }^{1}$, N Voloscuka ${ }^{1}$, N Zamjatina ${ }^{1}$

1. State Agency Infectology Center of Latvia, Riga, Latvia

Perevoscikovs J, Brila A, Firstova L, Komarova T, Lucenko I, Osmjana J, Savrasova L, Singarjova I, Storozenko J, Voloscuka N, Zamjatina N. Ongoing outbreak of aseptic meningitis in south-eastern Latvia, June - August 2010. Euro Surveill. 2010;15(32): pii=19639. Available online: http://www.eurosurveillance.org/ ViewArticle.aspx?Articleld=19639

An outbreak of aseptic meningitis has been ongoing in several areas of Latgale region, in the south-eastern part of Latvia since the end of June 2010. By 9 August 2010, 114 cases had been notified. Most of the cases were registered in the city and amalgamated municipality of Daugavpils and neighbouring territories. According to current evidence, two types of enteroviruses, coxsackie A-9 virus and echovirus 30, are the causative agents of the outbreak.

\section{Outbreak detection}

The most important causative agents of aseptic meningitis are different types of enteroviruses, including coxsakieviruses and echoviruses [1]. Enterovirus activity in populations may be either sporadic or epidemic [2]. Outbreaks of infection with coxsakieviruses and echoviruses have occurred in various years in different countries [3].

Onset of symptoms in the first case of aseptic meningitis connected with the current outbreak was on 30 June 2010, in Ilukste amalgamated municipality in the Latgale region, in the south-eastern part of Latvia. Since then new cases have been reported almost every day in different municipalities of the Latgale region, where $15 \%$ of the Latvian population live. By 9 August 2010, the total number of cases had reached 114 .

The aim of this article is to provide rapid epidemiological assessment of this ongoing outbreak and describe the prevention and control measures undertaken so far.

\section{Surveillance of aseptic meningitis in Latvia}

In Latvia, surveillance of aseptic meningitis is based on mandatory clinical (syndromic approach) and laboratory notification. The State Agency 'Infectology Center of Latvia' is responsible for epidemiological surveillance and control of infectious diseases in the country. All reported cases of aseptic meningitis are processed through an online computerised state infectious diseases surveillance and monitoring system (VISUMS).

\section{Outbreak investigation}

In order to investigate the outbreak, cases of aseptic meningitis were selected by the date of symptom onset from the VISUMS for descriptive epidemiological analysis of the outbreak for the period 30 June to 9 August 2010 and for analysis of seasonal trends for the period from January 2007 to July 2010.

From 30 June to 9 August 2010, 136 cases of aseptic meningitis were registered in total in Latvia (6 cases per 100000 population), 114 of whom were reported from Latgale region (33 cases per 100,000 population) (Figure 1).

Most cases were reported from the city and amalgamated municipality of Daugavpils $(n=74)$ and neighbouring amalgamated municipalities (Table). All patients were treated or continue to be treated in hospitals. Their clinical features were compatible with aseptic meningitis: fever, headache and vomiting. In this investigation, there were no case definitions for aseptic meningitis.

According to available information there was no increase of enteroviral meningitis in the border areas of neighbouring countries (Belarus and Lithuania).

The ages of the reported cases of aseptic meningitis ranged from two to 66 years. However, most cases (94 of $114,82 \%$ ) were children and adolescents (aged two to 19 years). Among the cases, 75 (66\%) were males and 39 (34\%) were females. The male:female ratio was 1.92:1 (Figure 2).

The previous largest outbreak of aseptic meningitis in Latvia occurred in Latgale region in August to November 2006, due to echovirus 30 infection [4]. By November 2006, the total number of cases had reached 408. A substantial increase of aseptic meningitis was observed also in 2007 in different parts of the country, including Latgale region, where $60 \%$ of all cases were registered (Figure 3). Echoviruses 6 and 18 were the dominant enteroviruses in 2007. 
The last case of aseptic meningitis before the current outbreak was reported from Daugavpils city at the end of May 2010. Coxsackie A-9 virus was detected in a stool sample from the case.

As of 9 August 2010, four cases of enteroviral meningitis have been laboratory confirmed in the amalgamated municipality of Ilukste in Latgale region: two cases with coxsackie A-9 virus (identified in stool samples) and two cases with echovirus 30 (identified in cerebrospinal fluid (CSF) samples). A further case of enteroviral infection with detected in stool sample coxsackie A-9 virus was reported at the beginning of July in Daugavpils city in a child with gastrointestinal symptoms only. These findings suggest at least two causative agents of the current outbreak.

Enteroviruses were also detected in stool or CSF samples from a further eight patients with aseptic meningitis and in two sewage samples from Latgale region. Typing results are pending.

\section{FIGURE 1}

Cases of aseptic meningitis by week of symptom onset and administrative territories, Latvia, 30 June - 9 August 2010 $(\mathrm{n}=136)$

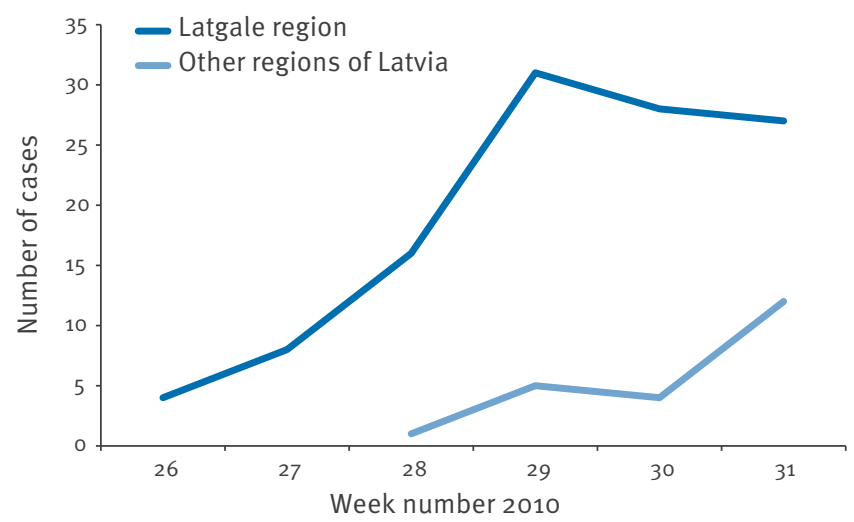

\section{TABLE}

Cases of aseptic meningitis by week of symptom onset, Latgale region, Latvia, 30 June - 9 August $2010(n=114)$

\begin{tabular}{|l|r|r|r|r|r|r|r|}
\hline \multirow{2}{*}{ Territory } & \multicolumn{7}{|c|}{ Week number 2010} \\
\cline { 2 - 9 } & 26 & 27 & 28 & 29 & 30 & 31 & Total \\
\hline Aglonas AM & 0 & 0 & 0 & 2 & 0 & 1 & $\mathbf{3}$ \\
\hline Dagdas AM & 0 & 0 & 0 & 0 & 1 & 0 & $\mathbf{1}$ \\
\hline Daugavpils city & 1 & 6 & 11 & 18 & 15 & 11 & $\mathbf{6 2}$ \\
\hline Daugavpils AM & 0 & 0 & 2 & 5 & 5 & 1 & $\mathbf{1 3}$ \\
\hline Ilūkstes AM & 2 & 2 & 2 & 5 & 1 & 3 & $\mathbf{1 5}$ \\
\hline Krāslavas AM & 0 & 0 & 1 & 1 & 6 & 11 & $\mathbf{1 9}$ \\
\hline Rēzeknes AM & 1 & 0 & 0 & 0 & 0 & 0 & $\mathbf{1}$ \\
\hline Total, Latgale region & $\mathbf{4}$ & $\mathbf{8}$ & $\mathbf{1 6}$ & $\mathbf{3 1}$ & $\mathbf{2 8}$ & $\mathbf{2 7}$ & $\mathbf{1 1 4}$ \\
\hline
\end{tabular}

AM: amalgamated municipality.
Although there are signs of geographical clustering, interviews with cases with aseptic meningitis did not indicate any epidemiological link between most cases. Nevertheless, eight clusters with secondary cases of aseptic meningitis were identified: one cluster with three cases in a children's institution, one cluster with three cases and five clusters with two cases in households and one cluster with two cases in children from a dancing group. The majority of cases $(n=80)$ went swimming in various lakes, rivers and ponds, thus excluding swimming water as the common source in this outbreak.

\section{Prevention and control measures}

In this outbreak, the following surveillance, prevention and control measures were undertaken:

- epidemiological investigation of cases of aseptic meningitis including interview with patients or their parents, and organisation of control measures in the affected settings attended by children;

\section{FIGURE 2}

Cases of aseptic meningitis by sex and age group, Latgale region, Latvia, 30 June - 9 August $2010(\mathrm{n}=114)$

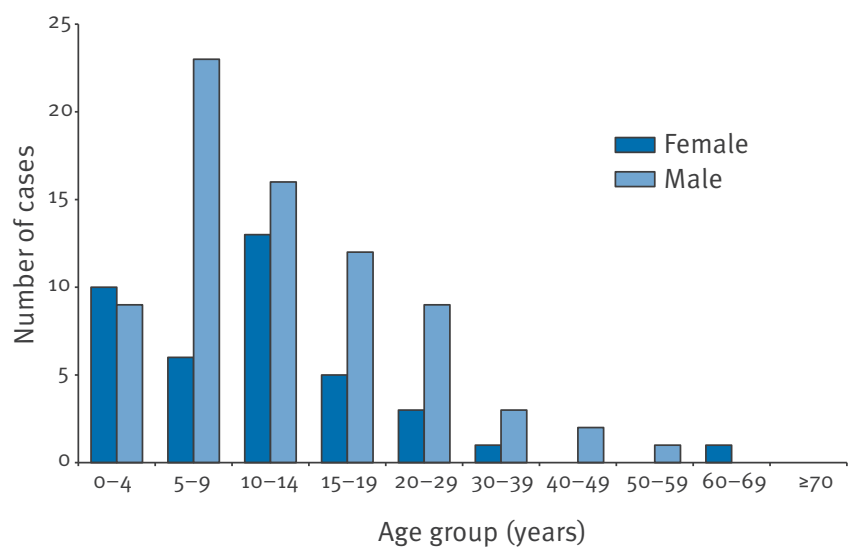

\section{FIGURE 3}

Cases of aseptic meningitis by month of symptom onset, Latvia, 2007-2010a

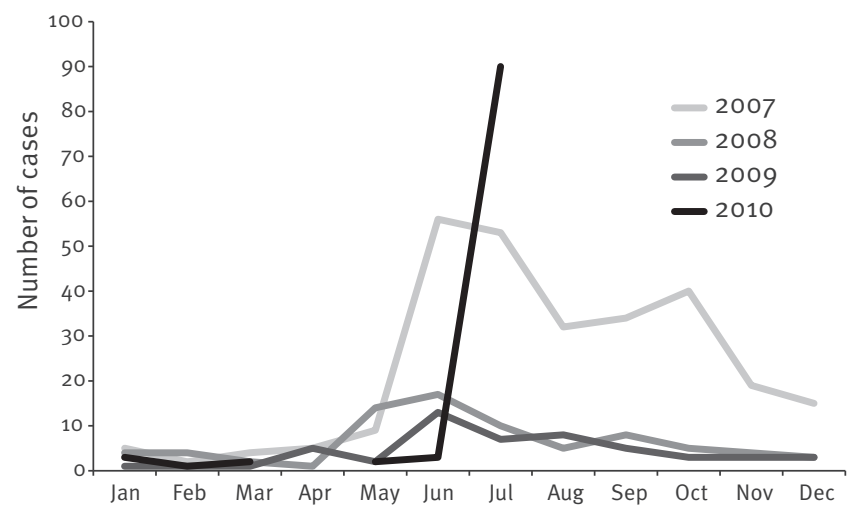

a For 2010, January to July only. 
- investigation of environmental samples (lake water, tap water and sewage water) to detect circulation of enteroviruses;

- daily data analysis of aseptic meningitis at the national level;

- regular publication of data analysis on the website of the Infectology Center of Latvia [5];

- consultations with and recommendations to the general public and target institutions, including publication of detailed information on prevention of enteroviral meningitis for the general public, childcare centres, schools and food handlers on the website of the Infectology Center of Latvia [6];

- standard operational plan drawn up for municipalities in Latgale region on prevention and control of enteroviral infection, information for clinicians on aseptic meningitis and recommendations for virological investigation of cases;

- communication with mass media on the prevention and control measures.

\section{Discussion and conclusions}

A large aseptic meningitis outbreak caused by at least two enteroviruses (coxsackie A-9 virus and echovirus 30) is still ongoing in the south-eastern part of Latvia. The epidemiological pattern of the outbreak (age and sex distribution of cases) corresponds to the usual characteristic of the enteroviral infection, with the majority of cases in males and young children or adolescents. The incidence of aseptic meningitis was high in 2006 and 2007, and low in 2008 and 2009. Although in previous non-epidemic years (2007-2009), seasonal increases of enteroviral meningitis began in May to June, this year the outbreak started later, at the end of June.

In view of the seasonal character (summer-autumn) of enteroviral infections and taking into account reopening of schools after the summer holidays, further spread, importation and transmission of infection to other Latvian regions cannot be excluded. The risk of international spread is assessed as not significant. Further monitoring and data analysis are to be performed on a regular basis.

\section{References}

1. Gorbach SL, Bartlett JG, Blacklow NR, editors. Infectious Diseases. 2nd ed. W.B.Saunedr Company; 1998:1408-1409.

2. Rotbart HA, editor. Human enterovirus infections. Washington: ASM Press;1995:271.

3. Evans AS, Kaslow RA, editors. Viral Infections of Human. 2nd ed. New York and London: Plenum Medical Book Company; 1997:599.

4. Perevoscikovs J, Lucenko I, Nikiforova R. Outbreak of enteroviral meningitis in Latvia, August - October 2006. Euro Surveill. 2006;11(40):pii=3060. Available from: http://www. eurosurveillance.org/ViewArticle. aspx? Articleld $=3060$

5. Infectology Center of Latvia. [Updated information on aseptic meningitis (meningitis serosa) outbreak in Latgale region]. Riga: Infectology Center of Latvia. Latvian. Available from: http://www.lic.gov.lv/?p=8470\&lang $=258$

6. Infectology Center of Latvia. [Recommendations for enteroviral meningitis (meningitis serosa) prophylaxis. Information for population]. Riga: Infectology Center of Latvia. Latvian. Available from: http://www.lic.gov.lv/docs/268/2010/ Enterovirusu_meningits_2010.pdf 